\title{
ASEAN Economic Community And Small-Medium Enterprises: An English School Perspective
}

\author{
Verdinand Robertua \\ Universitas Kristen Indonesia \\ Cawang, Kramatjati, Daerah Khusus Ibukota Jakarta 13630 \\ verdinand.robertua@uki.ac.id \\ Submitted: 25 January 2016, Accepted: 25 May 2016
}

\begin{abstract}
Abstrak
Dengan kontribusi sebesar 30-60\% Pendapatan Domestik Bruto dari negara-negara ASEAN, usaha kecil dan menengah (UKM) menjadi pelaku penting bagi ekonomi Asia Tenggara. Meskipun demikian, UKM menghadapi berbagai hambatan struktural, finansial dan akses terhadap modal, teknologi dan pasar.ASEAN memiliki peran penting di dalam mengembangkan UKM. Berbagai institusi di bawah ASEAN memiliki kemampuan untuk mengarahkan dan mendanai berbagai program pengembangan UKM. Masyarakat Ekonomi ASEAN (MEA) sebagai salah satu agenda liberalisasi regional memiliki dampak terhadap perkembangan UKM di negara-negara anggota ASEAN. Penelitian ini berusaha menjawab dampak MEA terhadap UKM di ASEAN dengan menggunakan English School Theory. Data diperoleh melalui wawancara dan analisis konten. Penelitian ini berkesimpulan bahwa ASEAN telah memiliki rencana komprehensif pengembangan UKM namun terhambat oleh koordinasi antara institusi ASEAN. Kata kunci: usaha kecil dan menengah, English School Theory, Masyarakat Ekonomi ASEAN
\end{abstract}

\begin{abstract}
Accounting for $30-60 \%$ of GDP of ASEAN member states and the largest source of employment for all economic actors, small medium enterprises is a very important economic actor in Southeast Asia. The SME sector in ASEAN, however, is confronted with a wide-range of structural, financial and other challenges, among which are limited access to finance, technologies and markets. ASEAN has many important roles in developing SMEs. ASEAN institutions can guide, direct, and fund many development programmes related to SMEs. Moreover, AEC, a new set of regional liberalization package, will have important consequences to SMEs' growth in the ASEAN member states. Therefore this paper will ask the impact of AEC to SMEs in ASEAN member states using English School Theory. It also asks the role of ASEAN in promoting SME development toward AEC. In this paper, interview and content analysis will do as the main data source. This paper concluded that ASEAN has developed a comprehensive empowerment plan through Strategic Action Plan for ASEAN SME Development but lack of coordination between ASEAN institutions has hindered the full implementation of the plan.

Keywords: Small and medium enterprises, English School Theory, ASEAN Economic Community
\end{abstract}

\section{INTRODUCTION}

ASEAN leaders have repeatedly conveyed their political will and commitment to building ASEAN Economic Community (AEC) by 2015. They establish ASEAN Vision 2020, signed the ASEAN Charter, and decided to accelerate ASEAN Community into 2015. ASEAN Charter puts in place the institutions and mechanisms to build up an ASEAN Community. ASEAN Vision 2020 consisted of three pillars: ASEAN Economic Community, ASEAN Socio- cultural Community and ASEAN political security community.

ASEAN Economic Community consists of four main elements: single market base, competitive economic region, equitable economic development, and integration into global economy (ASEAN Secretariat, 2009). ASEAN Economic Community Blueprint has been signed and adopted at the $13^{\text {th }}$ ASEAN Summit on 20 November 2007 in Singapore. 
Table 1. Significance of SMEs in the Economy in Selected Years (Economic Research Institute for ASEAN and East Asia, 2008)

\begin{tabular}{|c|c|c|c|c|c|c|c|c|}
\hline \multirow[t]{2}{*}{ Country } & \multicolumn{2}{|c|}{$\begin{array}{l}\text { Share of Total } \\
\text { Establishments }\end{array}$} & \multicolumn{2}{|c|}{$\begin{array}{l}\text { Share of Total } \\
\text { Employment }\end{array}$} & \multicolumn{2}{|c|}{ Share of GDP } & \multicolumn{2}{|c|}{$\begin{array}{l}\text { Share of Total } \\
\text { Exports }\end{array}$} \\
\hline & Share & Year & Share & Year & Share & Year & Share & Year \\
\hline Brunei & $98.2 \%$ & 2010 & $58 \%$ & 2008 & $23 \%$ & 2008 & - & - \\
\hline Cambodia & $99.8 \%$ & 2011 & $72.9 \%$ & 2011 & - & - & - & - \\
\hline Indonesia & $99.9 \%$ & 2011 & $97.2 \%$ & 2011 & $58 \%$ & 2011 & $16.4 \%$ & 2011 \\
\hline Lao & $99.9 \%$ & 2006 & $81.4 \%$ & 2006 & - & - & - & - \\
\hline Malaysia & $97.3 \%$ & 2011 & $57.4 \%$ & 2012 & $32.7 \%$ & 2012 & $19 \%$ & 2010 \\
\hline Myanmar & $88.8 \%$ & - & - & - & - & - & - & - \\
\hline Philippines & $99.6 \%$ & 2011 & $61 \%$ & 2011 & $36 \%$ & 2006 & $10 \%$ & 2010 \\
\hline Singapore & $99.4 \%$ & 2012 & $68 \%$ & 2012 & $45 \%$ & 2012 & - & - \\
\hline Thailand & $99.8 \%$ & 2012 & $76.7 \%$ & 2011 & $37 \%$ & 2011 & $29.9 \%$ & 2011 \\
\hline Viet Nam & $97.5 \%$ & 2011 & $51.7 \%$ & 2011 & - & - & - & - \\
\hline
\end{tabular}

In the competitive economic region, there are five pillars: (i) free flow of goods; (ii) free flow of services; (iii) free flow of investment; (iv) free flow of capital; and (v) free flow of skilled labor.

In the case of "equitable economic development", ASEAN developed the Initiative for ASEAN Integration (IAI), which identified the needs of CLMV countries (Cambodia, Lao, Myanmar and Vietnam) and the promotion of small and medium enterprises.

Accounting for $30-60 \%$ of GDP of ASEAN member states and the largest source of employment for all economic actors, small medium enterprises is a very important economic actor in Southeast Asia (ASEAN Secretariat, 2013). Indonesia, for example, is home to 55,2 million SMMEs which contributes to 57\% Indonesian GDP (Chandra \& Hattari, 12). SMEs are important in cyclical downturns and recessions. They cushion the impact on economies that more often than not comes from large enterprises (Nixon, 2009).

Single market and production means greater opportunities for SMEs to export their products to ASEAN market. A strong, dynamic and efficient SME sector will ensure the sustainable, inclusive and broadbased economic and social development. A vibrant SME sector is critical in supporting closer regional integration through the establishment of the ASEAN Community, particularly the ASEAN Economic Community (AEC). Thus, the encouragement and promotion of competitive and innovative SMEs is necessary in contributing to greater economic growth and social development towards more inclusive and broad-based integration of the ASEAN region.

The SME sector in ASEAN, however, is confronted with a wide-range of structural, financial and other challenges, among which are limited access to finance, technologies and markets. There is also the question of entrepreneurial spirit and management skills among ASEAN SMEs. These problems are compounded by the lack of information, inadequate capacity for compliance with standards and certification, and the absence of a more conducive business and policy environment.

In addition, there are the new trends of conducting business utilizing information and communications technology (ICT) with on-line linkages across the value chain as well as the outsourcing and networking strategies adopted by large enterprises and multinational companies (MNCs) which lack participation by SMEs. All these require SMEs and government to undertake proactive capacity building and other 
measures to ensure and sustain SME participation in supply networks and to sharpen SME competitiveness, flexibility and hence business sustainability.

The formation of SME-based clusters, and interfirm networks and linkages within ASEAN will help leverage collaboration and collective efficiency, including scale economies across the value chain, thus creating further opportunities for business development and supply linkages for SMEs and their entrepreneurs in the region.

There is additionally a need to create and promote a more conducive business and policy environment for SME development where Government, ASEAN institution and the private sector assume synergistic and complementary roles. The Government and ASEAN institutions act as a facilitator, while SMEs themselves are the engine of growth. Indeed, collaborative SME development programmes within a publicprivate partnership framework will ensure the continued economic growth and social development in the region. These programs can be achieved through structured and organized action plans and development initiatives, including though the introduction of wide-ranging capacity building and fiscal and financial incentive programmes, with SMEs and their entrepreneurs as the main target beneficiaries.

As one of international organization, ASEAN has many important roles in developing SMEs. Together with states, ASEAN institutions can guide, direct, and fund many development programmes related to SMEs. In the context of AEC, ASEAN has big responsibility to nurture SMEs. Moreover, AEC, a new set of regional liberalization package, will have important consequences to SMEs' growth in the ASEAN member states. It can be two-edge swords for SMEs. AEC can be opportunities to internationalize SMEs but in other hand it can threaten the SMEs by fiercer competition from big corporation.

Therefore, this paper will ask a question of: How AEC will affect SMEs in ASEAN member states using English School Theory in International Political Economy?

\section{THEORETICAL FRAMEWORK}

ENGLISH SCHOOL THEORY IN INTERNATIONAL POLITICAL ECONOMY

English School Theory (EST) is one of IR grand theory widely acknowledged by its comprehensive contribution in security and International Political Economy (IPE) studies. In IPE studies, EST attempted to examine the relationship between sovereignty, international trade, international organization and non-conventional issues such as environment and human rights.

English School Theory, pioneered by Martin Wight, Hedley Bull and Barry Buzan, answered this debate by splitting up IR into three divisions. Wight (1992), for example, provides three conceptions on IR, which are realism, rationalism, and revolutionism. Realism offers pessimistic worldviews and revolutions represented radical movement toward idealist normative goals. Rationalism is the middle ground between realism and revolutionism emphasizing the role of law and wisdom in IR.

Bull (1966) provided three basic conceptions of IR, which are international system, international society and world society. International system refers to power politics amongst states, and puts the structure and process of international anarchy at the center of its analysis. International society is about the institutionalization of shared interest and identity amongst states, and puts the creation and maintenance of shared norms, rules and institutions at the center of IR theory. Worlds society takes individuals, non-state organizations and ultimately the global population as a whole as the focus of global societal identities and arrangements, and puts transcendence of the statessystem at the centre of IR theory.

Furthermore, Buzan (2004) argues that there are six spectrum of international society; asocial, power political, coexistence, cooperative, convergence, confederative. Each of this spectrum has its own assumptions on environment and non-state actors. Asocial, power political and coexistence considered that sovereignty and international order as the ultimate goal of international society meanwhile coopera- 
tive, convergence and confederative are very active in promoting new issues and actors in IR such as International Political Economy.

There are some ES' key concepts that can be used to analyze IPE. This research will focus to concept of market and sovereignty. Market, like war and diplomacy, is a very old practice in human affairs, arguably perhaps the oldest candidate for the status of a primary institution defining the relations between the highest level of organized human grouping at any given time (Buzan \& Little, 2000). Market was the primary economic institution for much of human history until fairly recent times, often carrying with it secondary institutions such as the particular rights accorded to enclaves of foreign traders in most of the city-states and empires of the ancient and classical world until today.

For ES theorists, market means more than just trade and finance. Market becomes an institution when there is shared practice and norms for granting particular rights to particular individual and collective organization. It is a principle of organization and legitimation that affects both how states define and constitute themselves, what kind of other actors they give standing to, and how they interpret sovereignty and territoriality.

Another key concept was sovereignty. The emphasis on sovereignty will result to two perspectives; mercantilism and liberalism. Mercantilism is in harmony with balance of power, nationalism, and war. Liberalism has complex effects. It requires sovereignty/non-intervention to be reinterpreted to allow more porous borders.

Under mercantilism, states saw themselves in a zero-sum competition with others and sought to maximize their wealth, power, and autonomy, not least by seeking favourable trade balances and the accumulation of specie. Crudely put, mercantilism meant that self-reliance was preferred to trade because the national interest was defined in terms of an ability to wage war. On the other side was liberalism, which held that trade was a good in and of itself, lowering prices, increasing technological innovation, prosperity, and social dynamism, and reducing the incentives for war. Mercantilism enhanced the power of the state, while liberalism elevated the power of the market and a variety of non-state actors.

Two different perspectives and two different concepts will yield different result in terms key words, objects of investigation and recommended proposal. This battle not only affected the whole character of the IPE, but also radically altered the balance and meaning of the primary institutions of international society. For more than a century this struggle was a, and arguably the, central issue of international relations.

In addition to having major impacts on the other institutions of international society, the market also changes the composition of the actors who are in one way or another members of or at least participants in international society. Under liberal rules, both individuals and non-state actors have legal rights against the state even if those rights are granted by the state. In principle, liberalism as a doctrine and the market as a practice favour a minimal state and the maximum liberty for individuals consistent with maintaining social order. In practice this means the empowerment of civil society and the right of people to establish organizations for a wide range of purposes.

To convince the battle between market and sovereignty, the author will use the concepts to analyze globalization. Some allege that the most important result of globalization is the triumph of the market over the nation-state and the consequent end of national sovereignty. Economic forces are said to be eroding national boundaries so that governments lose control over their economies, and national economic systems converge toward a common model.

Market-oriented proponents of globalization consider this development as signaling a grand moment in human history; the supremacy of the market over the state and of economics over politics over the end of a human institution and of the political struggles responsible for war, domination and other problems. For critics of globalization, on the other hand, victory of the market means the end of the state 
as the protector of the economically weak against the economically strong, and the supremacy of ruthless market forces and those who control such forces.

\section{RESULT AND ANALYSIS}

ASEAN ECONOMIC COMMUNITY: A THREAT TO SMALLMEDIUM ENTERPRISES

The increasing interdependence of countries in a globalised world makes them more vulnerable to economic problems for smaller firms like the Asian financial crisis of the late 1990's. Smaller firms will find it difficult to compete on the global level as they lack the financial and technical resources that multinationals have. In addition they lack the economies of scale which results in lower cost per unit for the multi nationals.

Pricing could be a challenge since the smaller firms are likely to have high costs per unit. Larger firms have the capacity to undercut the smaller firms prices as a consequence of this competition between smaller and large firm would erode margins of smaller firms and some of them would end up making loses and winding up.

It would be difficult for smaller firms to attract a highly skilled work force because multi nationals have the capacity to pay better packages as they will have more financial resources. This would pose a challenge for smaller firms to operate efficiently and effectively. High promotional, advertising and branding costs are a barrier to entry for small firms.

Cultural and religious factors can also affect competitiveness of small firms. For instance, in countries where Islam is a dominant religion in which strict adherence to halal standards is a requirement, small firms may find it difficult to penetrate the market or to survive in such markets.

Import restrictions can also affect small firm competitiveness. For example, in some countries such as Egypt, where there is an import ban on raw materials small firms may find it difficult to penetrate in such markets without a diversified global market base. Smaller firms may find it a challenge on the global market in terms of meeting certain international standards imposed by certain markets.

Export restrictions may also pose a problem. In some markets there are restrictive export regulations which, smaller firms find difficult to comply with e.g, small firms in Africa exporting agricultural produce into European markets such as honey or paprika. Membership of a Trading blocs such Common Market For Eastern and Southern Africa COMESA, Southern African Development Community SADC and the European Union EU, inter alia, could be another source of hindrance to smaller firms. Countries that are not members of such trading blocs may find it difficult to trade with member countries. Further other government policies such as high taxes are a disincentive to investment. Small firms are likely to be affected by such taxes.

Unlike multinationals, small firms are likely to suffer currency exchange losses. This is because small firms may not have capacity to hedge against such losses. Multinationals, operate in different markets and can easily cushion such effects. Multinationals have the capacity to produce better and cheaper goods as a result of the superior resource endowments such as modern technology and have larger budgets for research and development as compared to smaller firms. Purchase Power Parity is another factor to consider e.g, multinationals can procure inputs in countries where the currency has a higher PPP.

Globalization poses new challenges for SMEs by leading them to at least partially integrate the consequent idea of global change in their strategy. The expansion of markets does not mean that only large businesses will be able to profit fully from this trend. There is no correlation between large market and large business. Whatever the cost, to encourage the competitiveness of large national businesses. A fish that has become bigger and bigger in its pond will be eaten when it reaches the sea; it is better to teach it how to fight when it is small so that it can deal with the competition, wherever it is.

On the other hand, the internal factors constraining the globalization of SMEs are lack of experience on their part, insufficient resources and an excessive 
Table 2. Level of the education of the Owners/Entrepreneurs in Microenterprises (MIEs) and Small and Medium Enterprises (SMEs) Indonesia (2006) (\%)

\begin{tabular}{|c|c|c|c|}
\hline \multirow{2}{*}{ Level of Education } & \multicolumn{3}{|c|}{ Scale } \\
\hline & MIE \& SE & $\begin{array}{l}\text { ME (Medium } \\
\text { Enterprises) }\end{array}$ & MIE \& SME \\
\hline Not completed primary education & 12.20 & 7.97 & 16.09 \\
\hline Completed primary education & 28.87 & 21.29 & 31.30 \\
\hline Completed first level secondary education & 23.04 & 19.58 & 22.10 \\
\hline Completed second level secondary education & 30.42 & 37.54 & 26.87 \\
\hline Completed academic level education (D1, D2, D3) & 1.96 & 3.53 & 1.44 \\
\hline $\begin{array}{l}\text { University Diploma } \\
\text { Total }\end{array}$ & 3.51 & 10.09 & 2.20 \\
\hline
\end{tabular}

Source: BPS quoted in Tambunan(2009)

perception of risk. The major external factors are national information networks that are inadequate or poorly connected internationally, deficient complementary regional resources and assistance programs that are maladapted to SME requirements. In a number of countries, the positive factors appear to be gaining ascendance over the negative.

\section{INDONESIAN SMES IS LEFT BEHIND SMES?}

The integration of SMEs in the ASEAN market is the key issue considered in this paper. It is a common view that, in a highly integrated global market, SMEs suffer from a twofold problem: on the one hand, asset constraints and limitations in critical resources restrict the capability to compete in a global environment; on the other hand, local markets and niches are being attacked by powerful Multinational Corporation.

As a matter of fact, if the capability to cope with the global market is a must for real competition, we find that most of the competitive advantages are sizerelated; as a consequence, a question which we frequently hear is: How can SMEs compete against large firms in the global market? In our opinion, the keyquestion for SMEs might better be reshaped as follows: which global-business opportunities might be better exploited by SMEs? We claim that, while some business opportunities might be successfully exploited by large corporation as far as they can internalise (or control) the critical resources and competencies needed for these enterprises, there might also be business opportunities (e.g., short-term ones) that big companies would find too complex, or too risky to exploit. These opportunities might well be exploited by a network of SMEs with reduced investments. (Bruch \& Hiemenz, 1984) Argues that SMEs are supposed to have advantages over large-scale industries because:

- SMEs are labor-intensive and use relatively simple techniques of production that correspond to the abundance of labor and the scarcity of physical and human capital that prevail in most developing countries

- SMEs demonstrate a higher degree of efficiency in using capital and in mobilizing savings, entrepreneurial talent and other resources that otherwise remain idle.

Schmitz (2004) further argues the advance of SMEs relied on governance triangle comprising: a) local policy network, b) lead firms of global chains, and c) a global policy network concerned with the setting and monitoring of standards. His key point is that small enterprises have to interact with the sector-specific 
global governance structure and that the options and limits for local action arise from this interaction.

SMEs in ASEAN face tough challenges to acquire global standard and integrate into global economy. This paper will focus to SME's experience in Indonesia. In 1997, Indonesia have 39,7 million SMEs and in 1998 economic crisis, 3 million SMEs went bankrupt. There are two characteristics of Indonesian SMEs, clustering. Many SMEs in the same core business are located in one place. For example, Jepara, Cirebon and Solo are famous for their wooden furniture and Cibaduyut for shoes industry. Another characteristic is Indonesian SMEs face many development constraints: human resources power, financing, skills upgrading, etc. Indonesian SMEs employ mostly low-skilled workers and use traditional/old (many often own made/modified).

Table 3. Sources of capital in Indonesian Manufacturing MIs and SEs, 2005 (\%)

\begin{tabular}{lll}
\hline Source of Capital & Mls & SEs \\
\hline Own money & 82.41 & 68.85 \\
Borrow money & 2.86 & 1.75 \\
Own money and borrow & 14.73 & 29.40 \\
Total & 100 & 100 \\
\hline
\end{tabular}

Source: BPS quoted in Tambunan (2009)

According to ASEAN SME Policy Index by Economic Research Institute for ASEAN and East Asia, Indonesian SMEs have critical problems in technology and technology transfers and effective representation of SME interest. Business registration and start-up remains cumbersome and costly. The long administrative procedures/steps and the presence of unofficial costs remains key disadvantages of Indonesian red-tape bureaucracy. However, the legal and regulatory framework on credit in Indonesia has been largely in place and is quite advanced to enable access to finance.

Singapore has the most developed infrastructure and support system to develop their SMEs. The overall SME Policy Index for Singapore is far more than ASEAN average which indicates that Singapore has one of the strongest foundations in the area of technological capabilities, regional integration, infrastructure and support systems, and strong regulatory and institutional framework for intellectual property rights. The average index score of Malaysia is also above the ASEAN average and Thailand has performed at an intermediary level. (Economic Research Institute for ASEAN and East Asia, 2008)

\section{ASEAN POLICY BLUEPRINT FOR SME DEVELOPMENT}

As part of the third pillar of the ASEAN Economic Community (AEC) Blueprint on Equitable Economic Development, the ASEAN member's states have reiterated their commitment to foster a strong, dynamic and efficient SME sector. The ASEAN Small and Medium Enterprises Agencies Working Group (SMEWG) is responsible for formulating policies, programs, and activities to foster SME development. It also serves as a consultative and coordination forum for SME agencies. SMEWG meetings are convened regularly twice a year.

The $1^{\text {st }}$ SMEWG meeting was held in Jakarta, Indonesia, on 24 April 1995. The ASEAN Plan of Action on Small and Medium Enterprises Development and the Terms of Reference (TOR) for the SMEWG were endorsed at the $37^{\text {th }}$ ASEAN Economic Ministers (AEM) Meeting held on 7-9 September 1995 in Bandar Seri Begawan, Brunei Darussalam. At the $10^{\text {th }}$ SMEWG meeting, a brainstorming session on the ASEAN SME Development Decade (ASDD) 2002 - 2012 was held on 12 March 2002 in Manila, the Philippines. To accelerate the transformation and integration of regional SMEs into a competitive and dynamic supplier of the global and regional markets, the ASEAN Policy Blueprint for SME Development (APBSD) 2004 - 2014 was considered and endorsed at the $36^{\text {th }}$ AEM Meeting held on 3 September 2004 in Jakarta, Indonesia (ASEAN Secretariat, 2012). The APBSD outlines a framework for SME development in the ASEAN region and comprises of strategic work programmes, policy measures and indicative outputs. 
In 2009, following the sixth year of implementation of the APBSD, the AEM agreed to undertake a stock-taking exercise to review the implementation of the APBSD. Subsequently, the ASEAN country leaders at $14^{\text {th }}$ ASEAN Summit on 27 February - 1 March 2009 in Hua Hin, Thailand, tasked the AEC Council to develop a concrete plan of action aimed at enhancing the competitiveness and resilience of the SMEs in the region. In operationalizing this mandate, the SMEWG decided to develop the Strategic Action Plan for ASEAN SME Development (2010 - 2015).

The Plan defines the mission, objectives, guiding principles, current status, and future policies and programs for ASEAN SME Development. It aims to provide specific activities to be conducted in the short and medium term, wider dissemination of information on regional activities to ASEAN SMEs, and implementation of national and regional SME policies and programmes. It also shall promote SME development through improving access to financing and technology, strengthening export capacity, utilization of ICT solutions, enhanced capability to innovate and strengthened human resource development through regional programmes. The plan shall also support mechanisms that promote access to information, database development and dissemination of best practices.

\section{CONCLUSION}

As suggested by English School of International Political Economy, individual ASEAN states still retain key roles in promoting SME development toward the ASEAN Economic Community. ASEAN Business Advisory Council and ASEAN Secretariat played complementary roles in executing ASEAN Policy Blueprint for SME Development by searching donors, conducting the policy, and monitoring and evaluating the program.

SMEs have to find ways to compete with multinationals in the ASEAN Economic Community and ASEAN have focused to empower SMEs through ASEAN Economic Community Work Plan and ASEAN Policy Blueprint for SME Development.
However, the progress of the work plan implementation is slow and lagged behind the large multinationals that have started building regional production bases for the ASEAN market. There are disappointments from APINDO that government has no serious commitment to implement the work plan.

Constraint of financial access, human resources and information are key priorities for ASEAN officials to overcome. ASEAN Business Advisory Council (ABAC) mentioned that keeping track of Policy developments for SMEs is challenging. National governments should be serious in translating the Policy into real activities. ABAC reported that if SMEs read that a certain agreement has been newly ratified by a number of member states, they will still not know what specific opportunities arise for them and by when these will become practical business reality. SMEs are the main stakeholder of ASEAN national economies and should be considered as the agent of development.

In the plan, by 2015, ASEAN SMEs shall be world-class enterprises, capable of integration into the regional and global supply chains, able to take advantage of the benefits of ASEAN economic community building, and operating in a policy environment that is conducive to SME development, exports and innovation. To achieve this, individual ASEAN states should apply a more detailed programs and monitoring toward the implementation of ASEAN Policy Blueprint and think about adding specific needs of SMEs in individual ASEAN states. Indonesia, for example, can raise programs in increasing awareness and capability in health and safety standard for food products.

Given the stake of SME development in ASEAN and the fact that the success of the regional integration needs to have vibrant and competitive SMEs to fully benefit from a deeper regional integration and narrow development gaps, a higher ASEAN body should be established, i.e., elevate the ASEAN SME Advisory Board to an ASEAN SME Ministers Meeting level which reports directly to leaders in coordinating regional efforts and mobilizing resources for SME 
development. These efforts will involve the integration of other regional initiatives (trade, investment, banking, and finance) in harmony with the SME development agenda.

Leader's mandate and statement is indeed important in establishing an ASEAN SME Ministerial meeting on SME Development. This involves the mandate to focus on a number of areas and commitment to set specific targets for reduction in time and cost for formal business registration, commitment to markedly improve information, advisory, technical services on quality control, operational improvements and managerial training and commitment to encourage dialogue partners to help out especially on technical assistance for SME access to finance (e.g., credit risk management, etc.

\section{REFERENCES}

ASEAN Secretariat, 2012. Directory of Innovative SMEs in ASEAN 2012, Jakarta: ASEAN Secretariat.

Bruch, M. \& Hiemenz, U., 1984. Small and Medium Scale Industries in ASEAN Countries: Agents or Victim of Development? Colorade: Westview.

Bull, H., 1966. Grotian Conception on International Society. In: Diplomatic Investigation: Essays in the Theory of International Politics. Michigan: Allen \& Unwin, pp. 51-73.

Buzan, B., 2004. From International to World Society: English School Theory and the Social Structure of Globalisation. Cambridge: Cambridge University Press.

Buzan, B. \& Little, R., 2000. International Systems in World History. Oxford: Oxford University Press.

Economic Research Institute for ASEAN and East Asia, 2008. ASEAN SME Policy Index 2014: Towards Competitive and Innovative ASEAN SMEs. Jakarta: Economic Research Institute for ASEAN and East Asia.

Schmitz, H., 2004. Local Enterprises in the Global Economy: Issues of Governance and Upgrading. Cheltenham: Edward Elgar.

Tambunan, T., 2009. Productivity in SME's Indonesia: Facts and Constraints, Jakarta: Trisakti University Press.

Wight, M., 1992. International Theory: The Three Tradition. New York: Holmes \& Meier. 